\title{
Multiplex PCR for simultaneous identification of $E$. coli O157:H7, Salmonella spp. and L. monocytogenes in food
}

\author{
Thuy Trang Nguyen ${ }^{1,4} \cdot$ Vo Van Giau ${ }^{2,4}$ Tuong Kha Vo ${ }^{3}$
}

Received: 30 August 2016/Accepted: 14 September 2016/Published online: 24 September 2016

(c) The Author(s) 2016. This article is published with open access at Springerlink.com

\begin{abstract}
The rapid detection of pathogens in food is becoming increasingly critical for ensuring the safety of consumers, since the majority of food-borne illnesses and deaths are caused by pathogenic bacteria. Hence, rapid, sensitive, inexpensive and convenient approaches to detect food-borne pathogenic bacteria is essential in controlling food safety. In this study, a multiplex PCR assay for the rapid and simultaneous detection of Escherichia coli O157:H7, Salmonella spp. and Listeria monocytogenes was established. The invA, stx and $h l y A$ genes specifically amplified DNA fragments of 284, 404 and $510 \mathrm{bp}$ from Salmonella spp., L. monocytogenes and E. coli $\mathrm{O} 157: \mathrm{H} 7$, respectively. The 16S rRNA gene was targeted as an internal control gene in the presence of bacterial DNA. The specificity and sensitivity of the multiplex PCR were performed by testing different strains. The multiplex PCR
\end{abstract}

T. T. Nguyen and V. V. Giau contributed equally to this research and the completion of the manuscript.

Vo Van Giau

vovangiau911@gmail.com

$\triangle$ Tuong Kha Vo

votuongkha@yahoo.com

1 Department of Pharmacy, Ho Chi Minh City University of Technology (HUTECH), 475A Dien Bien Phu Street, Ward 25, Binh Thanh District, Ho Chi Minh City, Vietnam

2 Department of Faculty of Food Technology, Ho Chi Minh City University of Food Industry (HUFI), 140 Le Trong Tan, Tan Phu district, Ho Chi Minh City, Vietnam

3 Vietnam Sports Hospital, Ministry of Culture, Sports and Tourism, Do Xuan Hop Road, My Dinh I Ward, Nam Tu Liem District, Hanoi, Vietnam

4 Department of BionanoTechnology, Gachon Medical Research Institute, Gachon University, Sungnam, Korea assay was able to specifically simultaneously detect ten colony-forming unit $/ \mathrm{mL}$ of each pathogen in artificially inoculated samples after enrichment for $12 \mathrm{~h}$. The whole process took less than $24 \mathrm{~h}$ to complete, indicating that the assay is suitable for reliable and rapid identification of these three food-borne pathogens, which could be suitable in microbial epidemiology investigation.

Keywords Multiplex PCR - Simultaneous - Detection · Food-borne pathogen

\section{Introduction}

Food-borne diseases, which are mainly caused by foodborne pathogens, are a serious health hazard in both developing and developed countries. Escherichia coli O157:H7, Salmonella spp. and Listeria monocytogenes are commonly considered as food-borne pathogens in many countries (Cetinkaya et al. 2014; Modzelewska-Kapituła et al. 2014; Nowak et al. 2007; Wang et al. 2007; Zhou et al. 2014). Salmonella illnesses are commonly associated with poultry and eggs, along with meat, unpasteurized milk or juice, cheese, contaminated raw fruits and vegetables, spices and nuts, through consumption of contaminated salmonellosis (Modzelewska-Kapituła et al. 2014; Nowak et al. 2007; Zhou et al. 2014). The invA, a gene of Salmonella, contains those sequences that are unique to this genus and has been proved as a suitable PCR target with potential diagnostic applications (Jamshidi et al. 2009). In addition, approximately 634 people were infected by Salmonella heidelberg from the farms chicken, according to the recent reports by the Center for Disease Control and Prevention in 2013 and 2014. Listeriosis, a serious infection usually caused by eating food contaminated with the 
bacterium L. monocytogenes (Ahmed et al. 2015), has a high case fatality rate $(20-30 \%)$ in immunocompromised populations (Chen and Knabel 2007). It is considered a hazardous agent in the food industry, and L. monocytogenes can be detected in a large variety of vegetable food products as well as animal products (Mead et al. 1999). L. monocytogenes is found in a variety of foods such as milk, milk products, eggs, poultry and meat (Amagliani et al. 2004). L. monocytogenes became a frequent pathogen involved more frequently in sporadic severe illnesses and outbreaks of food-borne infections. hly $\mathrm{A}$ is the gene that codes for the listeriolysin $\mathrm{O}$ toxin which is present in the genome of pathogenic L. monocytogenes. Since this gene codes for the toxin of the pathogen, it is necessary for virulence and is used for identifying $L$. monocytogenes in the presence of other Listeria strains (Churchill et al. 2006). According to recent reports by the CDC, there were 11 multistate outbreaks of Shiga toxin-producing E. coli in the USA from 2011 to 2014 with six of them attributed to E. coli $\mathrm{O} 157: \mathrm{H} 7$. The transmission of E. coli $\mathrm{O} 157: \mathrm{H} 7$ remains a major public health concern worldwide due to its low infectious dose. It is highly virulent; an inoculation of less than 10-100 CFU of E. coli O157:H7 is sufficient to cause infection (Coffey et al. 2011). E. coli O157:H7 may cause sporadic or epidemic cases of diarrhea, often with bloody stools, due mainly to the ingestion of contaminated food products (Chase-Topping et al. 2007). Shiga toxin (Stx) is one of the major virulence factors causing hemorrhagic colitis and hemolytic uremic syndrome involved in E. coli O157:H7 pathogenesis (Melton-Celsa et al. 2012) and are identified as stx1, stx1c, stxfc, stx2, stx2e, stx2d and stx2g (Gobius et al. 2003). These genes code for the toxin of the pathogen; it is necessary for virulence and useful for identifying E. coli $\mathrm{O} 157: \mathrm{H} 7$ in the presence of other strains. Some studies have employed one primer which could detect both the Stx1 and Stx2 genes (Aranda et al. 2007; Toma et al. 2003). Hence, the presence of bacterial pathogens in food poses a potential risk of infection in human health. Thus, the development of a rapid, cheap and sensitive method for the detection of these pathogens in food is required not only for improving food safety, but also for protecting human health.

Currently, the proposed approaches for the detection of food-borne pathogens is mainly the culture-based bacterial isolation and identification, but this is probably tedious and time-consuming (2-3 days) (Zhao et al. 2014). The application of genetic-based techniques is able to detect the pathogenic bacteria with greater sensitivity and reliability than conventional culture methods. PCR is more than a promising method; it has been applied with success in various protocols used for pathogen detection (Giau et al. 2016; Lee et al. 2014; Rahn et al. 1992; Zhang et al. 2009), particularly multiplex PCR assay (Xu et al. 2012).
Interestingly, multiplex PCR (mPCR) allows multiple gene analysis of bacteria at the same time in a single reaction tube simultaneously, saving time and reagents. A rapid, sensitive and specific method that would allow detection of multiple pathogens simultaneously from different types of foods would be very valuable for the food industry and regulatory agencies. Thus, keeping the above in view, we developed a multiplex PCR for the rapid and simultaneous detection of three epidemic food-borne pathogens: E. coli O157:H7, Salmonella spp., and L. monocytogenes. The performance of the multiplex assay, including its sensitivity, specificity and precision in qualitative analyses, was comprehensively evaluated in comparison with single target assays. The capacity of the proposed assay to detect multiple target pathogens simultaneously was also performed, and the effect of non-target interference on the assay performance was evaluated. The results obtained with artificially contaminated food samples show that the multiplex assay can simultaneously detect these three target food-borne pathogens in foods with high sensitivity and reliability.

\section{Materials and methods}

\section{Bacterial strains and cultivation conditions}

A total of 16 bacterial strains were used for evaluating the specificity of the multiplex PCR assay in this study, including 5 target bacterial strains and 11 other bacterial strains. In which, three strains E. coli O157:H7 were obtained from previously worked (Giau et al. 2016). The strains were verified by biochemical and immunologic methods, stored at $-80{ }^{\circ} \mathrm{C}$ in $10 \%$ glycerol and grown in Luria-Bertani (LB) (Oxoid, UK) at $37^{\circ} \mathrm{C}$ as listed in Table 1. The plate count method was used to measure the level of colony-forming unit (CFU) of each bacterium on LB agar medium. In this study, artificially contaminated samples were inoculated using the simultaneous enrichment broth (SEB) for simultaneous enrichment of three pathogenic bacteria, which was described previously by Kobayashi et al. (2009).

\section{Pathogen detection by the conventional culture method}

For detection of $E$. coli O157:H7, $25 \mathrm{~g}$ of each sample was diluted in $225 \mathrm{~mL}$ of modified tryptone soya broth (Mtsb, Oxoid, UK), added with novobiocin, homogenized for 2 min at $260 \mathrm{rpm}$ using a Stomacher (Model 400 circulator, Seward, Norfolk, England) and incubated for 18-24 h at $41.5^{\circ} \mathrm{C}$, as well as the remaining steps, according to the ISO 16654 (2001) method. After the enrichment and 
Table 1 Bacterial strains and their sources employed in this study

\begin{tabular}{clll}
\hline No & Bacteria & Serovar & Source \\
\hline The target strains & & \\
1 & E. coli & O157:H7 & NIHE \\
2 & E. coli & O157:H7 & HCMUS \\
3 & E. coli & O157:H7 & NLU \\
4 & Salmonella enteritidis & & ATCC13076 \\
5 & Listeria monocytogenes & ATCC19111 \\
The non-target strains & & \\
1 & E. coli & & ATCC 11775 \\
2 & E. coli & ATCC 25922 \\
3 & E. coli (Ahmed et al. 2015) & Clinical isolate \\
4 & E. coli (Amagliani et al. 2004) & & Clinical isolate \\
5 & E. coli (Aranda et al. 2007) & Chicken isolate \\
6 & E. coli (Cetinkaya et al. 2014) & & Beef isolate \\
7 & E. coli (Coffey et al. 2011) & Salad isolate \\
8 & Clostridium perfringens & ATCC13124 \\
9 & Bacillus cereus & ATCC11778 \\
10 & Shigella sonnei & ATCC 9290 \\
11 & V. cholerae & ATCC17802 \\
\hline
\end{tabular}

ATCC American Type Culture Collection, NIHE National Institute of Hygiene and Epidemiology, HCMUS HCM University of Science, $N L U$ Nong Lam University

immunomagnetic concentration steps, the selective and differential isolation of enterohemorrhagic $E$. coli $\mathrm{O} 157: \mathrm{H} 7$ was carried out on MacConkey agar with sorbitol, cefixime, and tellurite (CT-SMAC, Oxoid, UK) and incubated overnight at $42{ }^{\circ} \mathrm{C}$. From each sample, one well-isolated suspected colony was transferred to tryptone soy agar (Oxoid) and incubated for $24 \mathrm{~h}$ at $37^{\circ} \mathrm{C}$. Subsequently, one isolate from the subculture was further tested for agglutination with an E. coli O157:H7 latex test kit (BectonDickinson, USA) for serogroup O157:H7 confirmation. For detection of Salmonella spp., each $25 \mathrm{~g}$ food sample was diluted with $225 \mathrm{~mL}$ of sterile Buffered Peptone Water (Merck, Germany) and pummeled in a Stomacher apparatus for $2 \mathrm{~min}$; the mixture was then incubated for $18 \mathrm{~h}$ at $37^{\circ} \mathrm{C}$. One milliliter of the culture was added to $10 \mathrm{~mL}$ of Rappaport-Vassiliadis soy peptone broth (Mer$\mathrm{ck}$, Germany) and incubated at $42.5^{\circ} \mathrm{C}$ for $18 \mathrm{~h}$. One loopful of the culture was then streaked onto xylose lysine deoxycholate agar (Merck, Germany) and incubated at $37{ }^{\circ} \mathrm{C}$ for $24 \mathrm{~h}$. The resulting presumptive Salmonella colonies were tested with biochemical screening and serological confirmation using Salmonella polyvalent O, O1 antisera (Becton-Dickinson, USA). For detection of $L$. monocytogenes, $25 \mathrm{~g}$ of the food samples was mixed with $225 \mathrm{~mL}$ of sterile Fraser Broth Listeria enrichment broth (Merck, Germany) and pummeled in a Stomacher for $1 \mathrm{~min}$, followed by incubation for $48 \mathrm{~h}$ at $30^{\circ} \mathrm{C}$. One loopful of the culture broth was streaked onto chromogenic Listeria agar with selective supplement (Oxoid, Hampshire, UK) and incubated at $37{ }^{\circ} \mathrm{C}$ for $48 \mathrm{~h}$. Presumptive colonies were streaked onto horse blood agar and TSA plates and incubated at $35^{\circ} \mathrm{C}$ for $48 \mathrm{~h}$. The resulting presumptive Listeria colonies were submitted for biochemical screening (oxidase test, catalase test and Gram staining).

\section{Primers and internal amplification control}

All oligonucleotide primers used in this study were synthesized by Sigma Company (Singapore). The target genes selected for their characteristic were the variants of stxl and stx2 (Shiga toxin) genes in E. coli O157:H7 (Toma et al. 2003), invA (invasion protein A) gene in Salmonella (Rahn et al. 1992) and the hlyA (transcriptional activator of the virulence factor) gene in L. monocytogenes (Shaw et al. 2004), all of which have been reported in recent publications as the most specific and reliable genetic targets for the five pathogens. The sequences of the three primer pairs for the multiplex PCR, their corresponding gene targets and the size of the expected amplification products are also shown in Table 2. In addition, the primer sets targeting the highly conserved regions of the bacterial 16S rRNA gene
Table 2 Primers selected for the multiplex PCR in this study

\begin{tabular}{lllll}
\hline Target pathogen & Primer sequence $\left(5^{\prime} \rightarrow 3^{\prime}\right)$ & Gene & PCR product (bp) & Reference \\
\hline $\begin{array}{l}\text { Escherichia coli } \\
\text { O157:H7 }\end{array}$ & $\begin{array}{l}\text { gagcgaaataatttatatgtg } \\
\text { tgatgatggcaattcagtat }\end{array}$ & Stxl, stx2 & 518 & Toma et al. (2003) \\
$\begin{array}{l}\text { Salmonella } \text { spp. } \\
\text { acagtgctcgtttacgacctgaat } \\
\text { agacgactggtactgatcgataat }\end{array}$ & invA & 284 & Rahn et al. (1992) \\
L. monocytogenes & $\begin{array}{l}\text { ggcaacaaactgaagcaagg } \\
\text { ttggcggcacattgtcac } \\
\text { gtattgaaagctctggcgg }\end{array}$ & hlyA & 404 & Shaw et al. (2004) \\
Bacterial DNA & 16S rRNA & 654 & Qu et al. (2006) \\
& tcgcttagtctctgaaccc & & & \\
\hline
\end{tabular}


were employed as an internal control of the presence of amplifiable bacterial DNA.

\section{Template DNA preparation after enrichment}

One $\mathrm{mL}$ of overnight culture was transferred into a microcentrifuge tube and centrifuged $12,000 \times \mathrm{g}$ for $3 \mathrm{~min}$ and re-suspended by vortex in sterile deionized water. The bacterial suspension was then boiled in $100{ }^{\circ} \mathrm{C}$ for $5 \mathrm{~min}$, followed by centrifugation at $12,000 \times g$ for $2 \mathrm{~min}$. Aliquots of the sample were prepared, frozen at $-20{ }^{\circ} \mathrm{C}$ and used as a reference template for single and multiplex PCR.

\section{Optimization of multiplex PCR conditions}

The multiplex PCR essay was optimized by varying single parameters while other parameters were maintained. The parameters that were examined were annealing temperature, final primer concentration for each target pathogen, extension time, cycle quantity and $\mathrm{Mg}^{2+}$ and dNTP concentrations. Ater PCR, the amplified multiple DNA fragments were separated in a $2 \%$ agarose gel stained with ethidium bromide, electrophoresed, and the DNA was visualized.

\section{Specificity and sensitivity of the multiplex PCR}

The multiplex PCR specificity was checked by examining the ability of the test to detect and distinguish non-target bacterial strains (Table 1) among these three target pathogens. In addition, to archive the method sensitivity, reference strains of E. coli O157:H7 (HCMUS), S. enteritidis ATCC13076 and L. monocytogenes ATCC19111 were grown on LB agar overnight. Small inocula were grown in LB broth for $10 \mathrm{~h}$ at $37^{\circ} \mathrm{C}$ with shaking, followed by serial dilutions in saline peptone water (Merck, Germany). Each dilution was spread on LB agar to determine the bacterial counts and also prepare DNA by the boiling method as described. The DNA mixture template was made by mixing the five DNA templates with equal concentrations, decimally diluted with each bacterium representing $10^{5}, 10^{4}$, $10^{3}, 10^{2}, 10^{1}$ and 1 colony-forming unit (CFU) and subjected to multiplex PCR.

\section{Examination of artificially contaminated samples}

Raw meat pork, chicken and vegetable salads were purchased from a local store. The sample was divided into different parts ( $25 \mathrm{~g}$ for each) and sterilized with radiation. The absence of the five target pathogens in the samples was confirmed by the conventional culture method as described above for each of them. The multiplex PCR assay for the detection of E. coli O157:H7, Salmonella. spp, and L. monocytogenes was evaluated with various food samples
Table 3 Specificity test for the multiplex PCR assay; a minus (-) indicates the absence of a band and a plus $(+)$ indicates the presence of a band

\begin{tabular}{|c|c|c|c|c|}
\hline Species & stx & $\operatorname{invA}$ & hlyA & $16 \mathrm{~S}$ rRNA \\
\hline E. coli $\mathrm{O} 157: \mathrm{H} 7$ (NIHE) & + & - & - & + \\
\hline E. coli $\mathrm{O} 157: \mathrm{H} 7$ (HCMUS) & + & - & - & + \\
\hline E. coli $\mathrm{O} 157: \mathrm{H} 7$ (NLU) & + & - & - & + \\
\hline Salmonella enterica ATCC13076 & - & + & - & + \\
\hline L. monocytogenes ATCC19111 & - & - & + & + \\
\hline E. coli ATCC 11775 & - & - & - & + \\
\hline E. coli ATCC 25922 & - & - & - & + \\
\hline E. coli (Ahmed et al. 2015) & - & - & - & + \\
\hline E. coli (Amagliani et al. 2004) & - & - & - & + \\
\hline E. coli (Aranda et al. 2007) & - & - & - & + \\
\hline E. coli (Cetinkaya et al. 2014) & - & - & - & + \\
\hline E. coli (Coffey et al. 2011) & - & - & - & + \\
\hline C. perfringens ATCC13124 & - & - & - & + \\
\hline B. cereus ATCC 11778 & - & - & - & + \\
\hline S. sonnei ATCC 9290 & - & - & - & + \\
\hline V. cholera AТCC 17802 & - & - & - & + \\
\hline
\end{tabular}

ATCC American Type Culture Collection, NIHE National Institute of Hygiene and Epidemiology, HCMUS HCM University of Science, $N L U$ Nong Lam University

in which each pathogen was inoculated at three differing levels as shown in Table 3. $25 \mathrm{~g}$ of each sample was transferred into a sterile PE bag containing $225 \mathrm{~mL}$ of sterile SEB medium with $1 \mathrm{~mL}$ of each level of inoculation of the three target pathogens in each concentration. After each 12-, 18- and 24-h incubation times at $37{ }^{\circ} \mathrm{C}$, a $1-\mathrm{mL}$ aliquot was collected in each period of time incubation, and bacterial DNA was extracted from enriched samples and subjected to multiplex PCR.

\section{Results}

\section{Development of the multiplex PCR protocol}

The multiplex PCR products were 284 bp for Salmonella spp., $404 \mathrm{bp}$ for L. monocytogenes, $518 \mathrm{bp}$ for E. coli $\mathrm{O} 157: \mathrm{H} 7$ and an internal control of the presence of $654 \mathrm{bp}$ for 16S rRNA of bacterial DNA, as indicated in Table 2 . First of all, the primer pair specificity for each bacterium was analyzed initially by single PCR with the PCR conditions previously published (Qu et al. 2006; Rahn et al. 1992; Shaw et al. 2004; Toma et al. 2003). All speciesspecific primer pairs produced a single PCR product with an expected product size, indicating species specificity of the used primers (Fig. 1, lanes 1-4). Then, all primer pairs were also tested for simultaneous identification of three of a mixture of the target DNA template of pathogens, using 


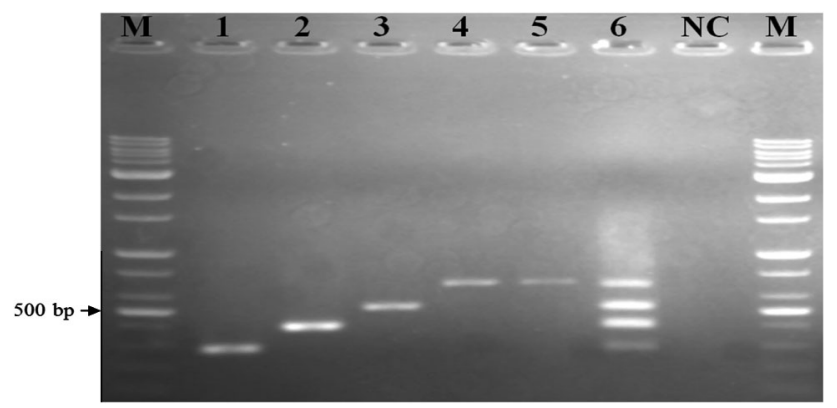

Fig. 1 Agarose gel electrophoresis showing monoplex and multiplex PCR-amplified products. M, 100-bp DNA marker; lane 1, Salmonella enteritidis ATCC13076; lane 2, L. monocytogenes ATCC19111; lane 3, E. coli O157:H7 (HCMUS); lane 4, 16S rRNA of bacterial DNA; lane 5, a mixture of the three DNA templates of pathogens before the optimizing; lane 6, the multiplex PCR-optimized conditions with four targets; and $\mathrm{NC}$, negative control

the multiplex PCR conditions based on single performance conditions as follows: $95^{\circ} \mathrm{C}$ for $15 \mathrm{~min}$ for the initial activation of $12.5 \mu \mathrm{L}$ of Taq PCR MasterMix (Promega), $0,5 \mu \mathrm{M}$ of each primer and $20 \mathrm{ng}$ of a mixture DNA template of pathogens in a $50 \mu \mathrm{L}$ reaction; 30 cycles of denaturing at $94{ }^{\circ} \mathrm{C}$ for $30 \mathrm{~s}$, annealing at $58{ }^{\circ} \mathrm{C}$ for $90 \mathrm{~s}$, and extension at $72{ }^{\circ} \mathrm{C}$ for $60 \mathrm{~s}$; and $72{ }^{\circ} \mathrm{C}$ for $10 \mathrm{~min}$ for a final extension. The respective bacterial amplicons were produced and separated on agarose gel electrophoresis. Unfortunately, the amplification of multiplex PCR product was not successfully done as faint bands for some amplicons, as shown on lane 5 of Fig. 1. The optimal condition of parameters for multiplex PCR protocol for simultaneous amplification of the three targets, namely, Salmonella spp., L. monocytogenes and E. coli $\mathrm{O} 157: \mathrm{H} 7$, were therefore determined. These parameters of the multiplex PCR assay required careful optimization, including annealing temperature, primer concentrations, extension time, Taq DNA polymerase concentration and $\mathrm{Mg}^{2+}$ concentration. The optimum $\mathrm{Mg}^{2+}$ concentration for multiplex PCR was examined by adding $1.0,1.5,2.0,2.5$ or $3.0 \mathrm{mM} \mathrm{Mg}^{2+}$, and finally $2.0 \mathrm{mM}$ of $\mathrm{Mg}^{2+}$ was produced for their respective targets. The dNTP concentration was increased stepwise from 100 to $500 \mathrm{mM}$, and the best results were obtained for $300 \mathrm{mM}$ of each dNTP. 2.0 U was optimal since different concentrations of Taq DNA polymerase were tested from 0.5 to $2.5 \mathrm{U}$ in a $50-\mu \mathrm{L}$ reaction. The concentration of the primer is of critical importance for multiplex PCR; hence, different combinations of primer ratios were subsequently tested, and the primer combination that was optimal for the protocol was $0.15 \mu \mathrm{M}$ each for Salmonella spp., $0.35 \mu \mathrm{M}$ each for L. monocytogenes, $0.25 \mu \mathrm{M}$ each for E. coli $\mathrm{O} 157: \mathrm{H} 7$ and $0.5 \mu \mathrm{M}$ each for $16 \mathrm{~S}$ rRNA of bacterial DNA. The optimal annealing temperature was $57.5^{\circ} \mathrm{C}$ to amplify simultaneously these four targets in the multiplex mixtures, and a 1.5-min extension with 35 cycles was used to complete the synthesis of all products since adequate resolution of all the amplified products could be seen. The lane 6 of figure 1 shows the yields of the expected multiplex PCR product, corresponding to Salmonella spp. (284 bp), L. monocytogenes (404 bp), E. coli O157:H7 (518 bp), and 16S rRNA of Bacterial DNA (654 bp), that were successfully amplified on agarose gel electrophoresis. Negative control reaction mixtures contained sterile distilled water instead of template DNA. The multiplex PCR-optimized conditions were used in all subsequent experiments.

\section{Specificity of the multiplex PCR assay}

The specificity of the multiplex PCR was conducted with the target strains and non-target bacterial strains. Table 3 shows the amplification products of the expected sizes obtained by PCR on five representative bacterial strains. E. coli O157:H7 (HCMUS), E. coli O157:H7 (NIHE), E. coli O157:H7 (NLU), S. enteritidis ATCC13076, and L. monocytogenes ATCC19111 that were positive in the multiplex PCR assay, while all non-target strains were negative in the assay and all non-target bacterial including E. coli ATCC 11775, E. coli ATCC 25922, E. coli (Ahmed et al. 2015), E. coli (Amagliani et al. 2004), E. coli (Aranda et al. 2007), E. coli (Cetinkaya et al. 2014), E. coli (Coffey et al. 2011), C. perfringens ATCC13124, B. cereus ATCC11778, V. cholerae ATCC17802 and S. sonnei ATCC 9290 were negative in the assay, whereas 16S rRNA was amplified as expected. No mispriming or non-specific amplification was observed. Expectedly, the size of each pathogen amplicon was obtained only from the target food-borne pathogens, resulting in $100 \%$ inclusivity and $100 \%$ exclusivity.

\section{Sensitivity of the multiplex PCR assay}

The sensitivity evaluation of the PCR assay was carried out using a series of target pathogen genomic DNA in tenfold dilution (from $10^{5}$ to $10^{0} \mathrm{CFU} / \mathrm{mL}$ ) of the target pathogens. There was a qualitative decrease in the intensity of the amplicons with the decrease of the DNA concentration. Interestingly, simultaneous specific detection of all three pathogens of all target strains including E. coli O157:H7 (HCMUS), S. enterica ATCC13076 and L. monocytogenes ATCC19111 could be successfully achieved down to $10^{2} \mathrm{CFU} / \mathrm{mL}$ (Fig. 2). The multiplex assay developed in this study was effective for the detection of target pathogens.

\section{Multiplex PCR protocol detection of artificially contaminated samples}

To validate and assess the multiplex PCR assay for its application to food samples, the minimum enrichment 


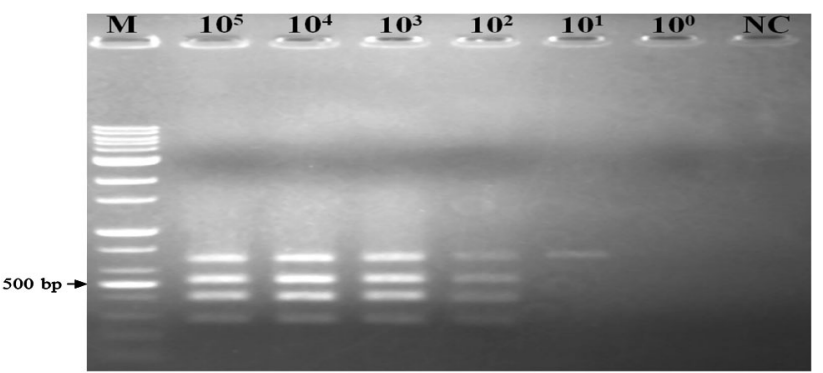

Fig. 2 Sensitivity of the multiplex PCR assay on samples obtained from DNA extracts mixed from serial dilutions $\left(10^{5}\right.$ to $\left.10^{\circ} \mathrm{CFU} / \mathrm{mL}\right)$ of the three pathogens. $M$ 100-bp DNA ladder, $N C$, negative control

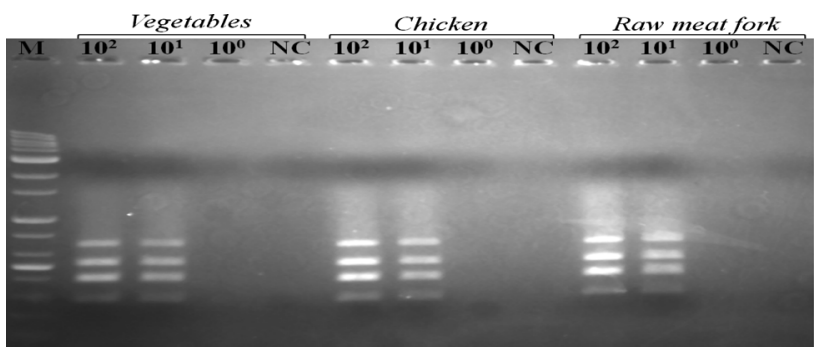

Fig. 3 The results of the multiplex PCR assay in the three categories of spiked food samples inoculated with different concentrations of the three pathogen mixtures after $12 \mathrm{~h}$ of enrichment. $M 100 \mathrm{bp}$ DNA ladder, $N C$, negative control

incubation time and limit of detection of the multiplex PCR using an SEB medium were conducted. Three types of food samples including raw pork, chicken and vegetable salads that were inoculated with E. coli O157:H7 (HCMUS), S. enterica ATCC13076 and L. monocytogenes ATCC19111 with four levels of the number of viable cells $\left(10^{\circ}, 10^{1}\right.$ and $10^{2} \mathrm{CFU} / \mathrm{ml}$ ) were analyzed as well as a noninoculated sample as negative control. The results demonstrated that after 12-h enrichment (Fig. 3), the multiplex PCR assay was able to correctly identify the presence of the three food-borne pathogens at all different inoculated levels and down to the lowest concentration of $10^{1} \mathrm{CFU} / \mathrm{mL}$ in all three types of food samples as shown in Table 4. Finally, the schematic representation of the steps involved in the multiplex PCR assay for the detection procedure is presented in Fig. 4.

\section{Discussion}

One of the 31 common food-borne pathogens identified, whereas bacteria are the primary causes of hospitalizations and deaths in the USA (Scallan et al. 2011). The common food-borne pathogenic bacteria which are responsible for most of the food-borne disease outbreaks are L. monocytogenes, E. coli O157:H7, Staphylococcus aureus, S. enterica, Bacillus cereus, Vibrio spp., Campylobacter jejuni, Clostridium perfringens and Shiga toxin-producing E coli (STEC) (Scallan et al. 2011; Zhao et al. 2014). While the conventional methods used to detect food-borne pathogen are time-consuming and laborious, the methods for rapid detection of food-borne pathogens are becoming more and more important in many food analyses (DíazLópez 2011). One of the most commonly used molecularbased methods for the detection of food-borne bacterial pathogens is PCR. Previously reported methods of multiplex PCR usually assay only for one (two or more target genes) or two pathogens. In the present study, the multiplex PCR for simultaneous identification of E. coli $\mathrm{O} 157: \mathrm{H} 7$, Salmonella spp. and L. monocytogenes strains in food was developed. The lowest detection level such as $10 \mathrm{CFU} / \mathrm{mL}$ had been achieved after $12 \mathrm{~h}$ of enrichment against three foodborne pathogens since this method was evaluated on three types of samples including raw meat fork, chiken and vegetable. Hence, this multiplex PCR assay combined with a pre-enrichment procedure could reliably and effectively detect the three major food-borne pathogens.

In a multiplexing assay, more than one target sequence, can be amplified by using multiple primer pairs in a reaction mixture. Almost all of the E. coli $\mathrm{O} 157: \mathrm{H} 7$ contains $s t x 1$ or/and $s t x 2$ gene, which is a virulence gene encoding a family of related toxins called Shiga (Stx). Generally, the stxl or/and stx2 gene has been proven to be E. coli O157:H7 (Gyles 2007; Orth et al. 2007). Hence, in this study, the identification of E. coli $\mathrm{O} 157: \mathrm{H} 7$ serotype using $s t x$ as a target was carried out. According to Toma et al. (2003), the primer stx was designed for the specific identification of E. coli $\mathrm{O} 157: \mathrm{H} 7$ which detects both stx 1 or/and stx2 genes, and this has also been applied in different studies (Aranda et al. 2007; Tobias and Vutukuru 2012; Toma et al. 2003). The invA gene of S. enterica selected in the study has already been proven to be an important diagnostic tool for detection, as it contains a sequence unique to this genus (Rahn et al. 1992; Shanmugasamy et al. 2011). While the hlyA gene codes for the action of listeriolysin protein (hlyA), which was mainly the potential of virulence pathogenic of $L$. monocytogenes, this was considered as the target gene for PCR detection (Dharmendra et al. 2013; Kaur et al. 2007). In addition, all selected primers were tested to examine the possible crossreactions of primers by homology searches, using the basic local alignment searching tool (BLAST) program, to find the best combination for developing multiplex PCR. Some studies also combined the different primers for all of the targets (Kim et al. 2007; Lee et al. 2014; Rahn et al. 1992; Zhang et al. 2009), considering that they should have similar melting temperatures $\left(T_{m}\right)$ and a similar size of target DNA to prevent differential yields in band amplification products. The primer pairs selected in this study 
Table 4 Multiplex PCR results of three pathogens from artificially inoculated three food sample matrices

\begin{tabular}{|c|c|c|c|c|c|}
\hline \multirow[t]{2}{*}{ Pathogens } & \multirow[t]{2}{*}{ Incubation time $(\mathrm{h})$} & \multirow[t]{2}{*}{$\mathrm{CFU} / \mathrm{mL}$} & \multicolumn{3}{|c|}{$\begin{array}{l}\text { Multiplex PCR results detection in food } \\
\text { samples }\end{array}$} \\
\hline & & & Raw pork & Chicken & Vegetable salads \\
\hline \multirow{12}{*}{$\begin{array}{l}\text { E. coli } \mathrm{O} 157: \mathrm{H} 7 \\
\text { (HCMUS) }(\text { stx })\end{array}$} & \multirow[t]{4}{*}{12} & 0 & - & - & - \\
\hline & & $10^{0}$ & - & - & - \\
\hline & & $10^{1}$ & + & + & + \\
\hline & & $10^{2}$ & + & + & + \\
\hline & \multirow[t]{4}{*}{18} & 0 & - & - & - \\
\hline & & $10^{\circ}$ & - & - & - \\
\hline & & $10^{1}$ & + & + & + \\
\hline & & $10^{2}$ & + & + & + \\
\hline & \multirow[t]{4}{*}{24} & 0 & - & - & - \\
\hline & & $10^{\circ}$ & - & - & - \\
\hline & & $10^{1}$ & + & + & + \\
\hline & & $10^{2}$ & + & + & + \\
\hline \multirow{12}{*}{$\begin{array}{l}\text { S. enterica ATCC } 13076 \\
\text { (invA) }\end{array}$} & \multirow[t]{4}{*}{12} & 0 & - & - & - \\
\hline & & $10^{\circ}$ & - & - & - \\
\hline & & $10^{1}$ & + & + & + \\
\hline & & $10^{2}$ & + & + & + \\
\hline & \multirow[t]{4}{*}{18} & 0 & - & - & - \\
\hline & & $10^{\circ}$ & - & - & - \\
\hline & & $10^{1}$ & + & + & + \\
\hline & & $10^{2}$ & + & + & + \\
\hline & \multirow[t]{4}{*}{24} & 0 & - & - & - \\
\hline & & $10^{\circ}$ & - & - & - \\
\hline & & $10^{1}$ & + & + & + \\
\hline & & $10^{2}$ & + & + & + \\
\hline \multirow{12}{*}{$\begin{array}{l}\text { L. monocytogenes } \\
\text { ATCC19111 (hlyA) }\end{array}$} & \multirow[t]{4}{*}{12} & 0 & - & - & - \\
\hline & & $10^{0}$ & - & - & - \\
\hline & & $10^{1}$ & + & + & + \\
\hline & & $10^{2}$ & + & + & + \\
\hline & \multirow[t]{4}{*}{18} & 0 & - & - & - \\
\hline & & $10^{\circ}$ & - & - & - \\
\hline & & $10^{1}$ & + & + & + \\
\hline & & $10^{2}$ & + & + & + \\
\hline & \multirow[t]{4}{*}{24} & 0 & - & - & - \\
\hline & & $10^{\circ}$ & - & - & - \\
\hline & & $10^{1}$ & + & + & + \\
\hline & & $10^{2}$ & + & + & + \\
\hline
\end{tabular}

were able to allow the successful multiplex PCR amplification after the optimization efforts (Fig. 1).

For specificity testing, the results showed that these four primer pairs in the multiplex PCR assay worked well independently, since multiplex PCR was performed on the mix of DNA extracts from the three food-borne pathogens and was compared to the same test performed on the pathogens individually (Fig. 1). For the optimization of the conditions, based on the yield of PCR products for the four target genes, the results showed that an optimal multiplex was well obtained, as decribed. In addition, the results of the specificity of primers in this study, as shown in Table 3, showed that these four primer pairs were specific for their corresponding target food-borne pathogens and the nontarget pathogenic bacteria also did not generate any amplification products. The sensitivity of the multiplex PCR assay was also determined using serial dilutions (from $10^{5}$ to $10^{1} \mathrm{CFU} / \mathrm{mL}$ ) of the target pathogens. Interestingly, 


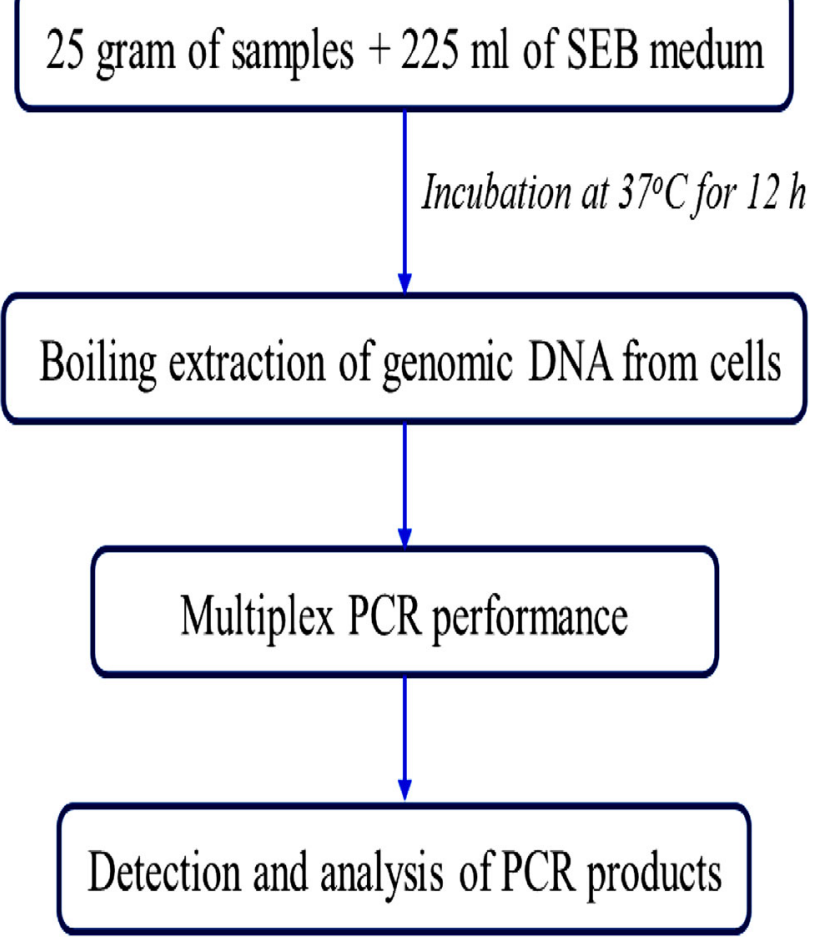

Fig. 4 The scheme of multiplex PCR assay for simultaneous detection of E. coli O157:H7, Salmonella spp., and L. monocytogenes in food

all target pathogenic bateria could be simultaneously detected down to $10^{2} \mathrm{CFU} / \mathrm{mL}$ (Fig. 2). This is more sensitive in comparison with the level of sensitivity of multiplex PCR assay for E. coli O157:H7, Salmonella and $L$. monocytogenes grown overnight in TSB which was $10^{6} \mathrm{CFU} / \mathrm{mL}$, as shown by Germini et al. (2009), and $10^{5} \mathrm{CFU} / \mathrm{mL}$ for E. coli O157:H7, Salmonella, S. aureus, $L$. monocytogenes and $V$. parahaemolyticus grown in Luria-Bertani (LB) by Kim et al. (2007).

In order to assess the detection sensitivity of the multiplex PCR assay for its application to food samples, three type of food samples including vegetable, chicken and raw meat pork were inoculated with different concentrations of three foodborne pathogens and incubated for 12, 18, and 24 $h$ in SEB enrichment medium. The results (Table 4) showed that after $12 \mathrm{~h}$ of enrichment, the multiplex PCR assay was able to correctly identify the presence of the three food-borne pathogens at all different inoculated levels and down to the lowest concentration of $10^{1} \mathrm{CFU} /$ $\mathrm{mL}$ in these three types of food samples. Comparatively, the highest sensitivity of $10^{\circ} \mathrm{CFU} / \mathrm{mL}$ for four pathogens, such as E. coli $\mathrm{O} 157: \mathrm{H} 7$, L. monocytogenes, S. enterica and $S$. Aureus, from eight artificially inoculated food samples was obtained after $24 \mathrm{~h}$ of enrichment (Zhang et al. 2009). Similarly, the simultaneous detection at concentrations of $10^{1} \mathrm{CFU} / \mathrm{mL}$ of five food-borne pathogens including
E. coli $\mathrm{O} 157: \mathrm{H} 7$, L. monocytogenes, S. enterica, V. parahaemolyticus and $S$. aureus was obtained in the previous multiplex PCR assays (Kim et al. 2007). The multiplex PCR assay described here can simultaneously detect three food-borne pathogens of E. coli O157:H7, Salmonella spp. and $L$. monocytogenes and was sufficient in specifically detecting $10^{1} \mathrm{CFU} / \mathrm{mL}$ in artificially inoculated food samples after enrichment for $12 \mathrm{~h}$.

In conclusion, the multiplex PCR assay was successful in developing a multiplex PCR method that detects simultaneously all of the three major virulence genes from food samples and reliable to detect the presence of $E$. coli $\mathrm{O} 157: \mathrm{H} 7$, Salmonella spp. and L. monocytogenes. Hence, the multiplex PCR assay has the potential to be used in routine diagnostic laboratories and also as a rapid screening tool in food testing laboratories to quickly identify food samples.

Acknowledgments This work was supported by the Vietnam Education Foundation for funding (VEF Fellowship to Vo Van Giau)

Authors' contributions Vo Van Giau collected the samples, performed the experiments, analyzed and interpreted the data and wrote the manuscript. The other authors read, reviewed and provided feedback on the final manuscript.

\section{Compliance with ethical standards}

Conflict of interest On behalf of all the authors, the corresponding author states that there is no conflict of interest.

Open Access This article is distributed under the terms of the Creative Commons Attribution 4.0 International License (http:// creativecommons.org/licenses/by/4.0/), which permits unrestricted use, distribution, and reproduction in any medium, provided you give appropriate credit to the original author(s) and the source, provide a link to the Creative Commons license, and indicate if changes were made.

\section{References}

Ahmed OM, Pangloli P, Hwang C-A, Zivanovic S, Wu T, D'Souza D, Draughon FA (2015) The occurrence of Listeria monocytogenes in retail ready-to-eat meat and poultry products related to the levels of acetate and lactate in the products. Food Control 52:43-48

Amagliani G, Brandi G, Omiccioli E, Casiere A, Bruce IJ, Magnani M (2004) Direct detection of Listeria monocytogenes from milk by magnetic based DNA isolation and PCR. Food Microbiol 21:597-603

Aranda KR, Fabbricotti SH, Fagundes-Neto U, Scaletsky IC (2007) Single multiplex assay to identify simultaneously enteropathogenic, enteroaggregative, enterotoxigenic, enteroinvasive and Shiga toxin-producing Escherichia coli strains in Brazilian children. FEMS Microbiol Lett 267:145-150

Cetinkaya F, Mus T, Yibar A, Guclu N, Tavsanli H, Cibik R (2014) Prevalence, serotype identification by multiplex polymerase chain reaction and antimicrobial resistance patterns of Listeria monocytogenes isolated from retail foods. J Food Saf 34:42-49 
Coffey B, Rivas L, Duffy G, Coffey A, Ross RP, McAuliffe O (2011) Assessment of Escherichia coli O157:H7-specific bacteriophages e11/2 and e4/1c in model broth and hide environments. Int J Food Microbiol 147(3):188-194

Chase-Topping ME, McKendrick IJ, Pearce MC, Macdonald P, Matthews L, Halliday J, Allison L, Fenlon D, Low JC, Gum G et al (2007) Risk factors for the presence of high-level shedders of Escherichia coli $\mathrm{O} 157$ on Scottish farms. J Clin Microbiol 45:1594-1603

Chen Y, Knabel SJ (2007) Multiplex PCR for simultaneous detection of bacteria of the genus Listeria, Listeria monocytogenes, and major serotypes and epidemic clones of L. monocytogenes. Appl Environ Microbiol 73:6299-6304

Churchill RL, Lee H, Hall JC (2006) Detection of Listeria monocytogenes and the toxin listeriolysin $\mathrm{O}$ in food. $\mathrm{J}$ Microbiol Methods 64(2):141-170

Dharmendra K, Soni A, Rakesh K, Singh B, Durg V, Singh B, Suresh K (2013) Characterization of Listeria monocytogenes isolated from Ganges water, human clinical and milk samples at Varanasi. India. Infect Genet Evol 14:83-91

Díaz-López A, Cantú-Ramírez RC, Garza-González E, Ruiz-Tolentino L, Tellez-Luis SJ, Rivera G, Bocanegra-Garcia V (2011) Prevalence of foodborne pathogens in grilled chicken from street vendors and retail outlets in reynosa, tamaulipas, Mexico. J Food Prot 74:1320-1323

Germini A, Masola A, Carnevali P, Marchelli R (2009) Simultaneous detection of Escherichia coli O157:H7, Salmonella spp., and Listeria monocytogenes by multiplex PCR. Food Control 20:733-738

Gobius KS, Higgs GM, Desmarchelier PM (2003) Presence of activatable Shiga toxin genotype $(\operatorname{stx}(2 \mathrm{~d}))$ in Shiga toxigenic Escherichia coli from livestock sources. J Clin Microbiol 41(8):3777-3783

Gyles CL (2007) Shiga toxin-producing Escherichia coli: an overview. J Anim Sci 85:E45-E62

Giau VV, Nguyen TT, Nguyen TKO, Le TTH, Nguyen TD (2016) A novel multiplex PCR method for the detection of virulenceassociated genes of Escherichia coli O157:H7 in food. 3 Biotech 6(1):5

Jamshidi A, Bassami MR, Afshari-Nic S (2009) Identification of Salmonella spp. and Salmonella typhimurium by a multiplex PCR-based assay from poultry carcasses in Mashhad-Iran. Int J Vet Res 3:43-48

Kaur S, Malik S, Vaidya V, Barbuddhe S (2007) Listeria monocytogenes in spontaneous abortions in humans and its detection by multiplex PCR. J Appl Microbiol 103:1889-1896

Kim JS, Lee GG, Park JS, Jung YH, Kwak HS, Kim SB, Nam YS, Kwon ST (2007) A novel multiplex PCR assay for rapid and simultaneous detection of five pathogenic bacteria: Escherichia coli O157:H7, Salmonella, Staphylococcus aureus, Listeria monocytogenes and Vibrio parahaemolyticus. J Food Prot 70:1656-1662

Kobayashi H, Kubota J, Fujihara K, Honjoh K, Ilo M, Fujiki N, Nakabe M, Oda S, Satoyama T, Takasu K, Nakanishi H, Miyamoto T (2009) Simultaneous enrichment of Salmonella spp, Escherichia coli O157:H7, Vibrio parahaemolyticus, Staphylococcus aureus, Bacillus cereus and Listeria monocytogenes by single broth and screening of the pathogens by multiplex realtime PCR. Food Sci Technol Res 15:427-438

Lee N, Kwon KY, Oh SK, Chang HJ, Chun HS, Choi SW (2014) A multiplex PCR, assay for simultaneous detection of Escherichia coli $\mathrm{O} 157: \mathrm{H} 7$, Bacillus cereus, Vibrio parahaemolyticus,
Salmonella spp., Listeria monocytogenes, and Staphylococcus aureus in Korean ready-to-eat food. Foodborne Pathog Dis 11(7):574-580

Mead PS, Slutsker L, Dietz V, McCaig LF, Bresee JS, Shapiro C, Griffin PM, Tauxe RV (1999) Food-related illness and death in the United States. Emerg Infect Dis 5(5):607-625

Melton-Celsa A, Mohawk K, Teel L, O'Brien A (2012) Pathogenesis of Shiga-toxin producing Escherichia coli. Curr Top Microbiol Immunol 357:67-103

Modzelewska-Kapituła M, Maj-Sobotka K (2014) Salmonella spp. occurrence in minced meat, meat preparations and mechanically separated meat in Poland. J Food Saf 34(2):126-131

Nowak B, Muffling TV, Chaunchom S, Hartung J (2007) Salmonella contamination in pigs at slaughter and on the farm: a field study using an antibody ELISA test and a PCR technique. Int J Food Microbiol 115:259-267

Orth D, Grif K, Khan AB, Naim A, Dierich MP, Wurzner R (2007) Shiga toxin genotype rather than the amount of Shiga toxin or the cytotoxicity of Shiga toxin in vitro correlates with the appearance of hemolytic uremic syndrome. Diagn Microbiol Infect Dis 59:235-242

Qu FF, Cai C, Zheng XJ, Zhang DB (2006) Rapid identification of Riemerella anatipestifer on the basis of specific PCR amplifying 16S rDNA. Wei Sheng Wu Xue Bao 46:13-17

Rahn K, De Grandis SA, Clarke RC, McEwen SA, Galán JE, Ginocchio C, Curtiss R 3rd (1992) Gyles CL Amplification of an invA gene sequence of Salmonella typhimurium by polymerase chain reaction as a specific method of detection of Salmonella. Mol Cell Probes 6(4):271-279

Scallan E, Hoekstra RM, Angulo FJ, Tauxe RV, Widdowson MA, Roy SL et al (2011) Foodborne illness acquired in the United States-major pathogens. Emerg Infect Dis 17:7-15

Shanmugasamy M, Velayutham T, Rajeswar J (2011) InvA gene specific PCR for detection of Salmonella from boilers. Vet World 4:562-564

Shaw JW, Alex C, Clarence IK (2004) Detection of PCR amplicons from bacterial pathogens using microsphere agglutination. J Microbiol Methods 56:395-400

Tobias J, Vutukuru S-R (2012) Simple and rapid multiplex PCR for identification of the main human diarrheagenic Escherichia coli. Microbiol Res 167:564-570

Toma C, Lu Y, Higa N, Nakasone N, Chinen I, Baschkier A et al (2003) Multiplex PCR assay for identification of human diarrheagenic Escherichia coli. J Clin Microbiol 42:2669-2671

Wang J, Zheng Z, Wang J (2007) Risk assessment of Salmonella in food of animal origin. Chin J Anim Quar 24:23-25

Xu YG, Cui LC, Li SL, Li DD, Zhang XB, Huo GC (2012) Development and clinical validation of a multiplex polymerase chain reaction-denaturing high-performance liquid chromatography method for the identification of foodborne diarrheagenic Escherichia coli. J Food Saf 32:6-12

Zhang D, Zhang H, Yang L, Guo J, Li X, Feng Y (2009) Simultaneous detection of Listeria monocytogenes, Staphylococcus aureus, Salmonella enterica and Escherichia coli O157:H7 in food samples using multiplex PCR method. J Food Saf 29:348-363

Zhao X, Lin CW, Wang J, Oh DH (2014) Advances in rapid detection methods for foodborne pathogens. J Microbiol Biotechnol 24(3):297-312

Zhou K, Zhong K, Long C, Han X, Liu S (2014) Development and validation of a predictive model for the growth of Salmonella enterica in chicken meat. J Food Saf 34:326-332 